\title{
International Clinical Experiences with Ex Vivo Lung Perfusion
}

\author{
Pablo G. Sanchez $\cdot$ Bartley P. Griffith
}

Published online: 30 January 2014

(C) Springer Science + Business Media New York 2014

\begin{abstract}
Ex vivo lung perfusion has been proposed as a method to identify good quality organs from the suboptimal donor pool, and as a method to reduce cold ischemic times by using a transportable system. As lung transplant centers adopt this new technology, encouraging reports are being published. In addition, single center experiences are now being validated by prospective and multicenter clinical trials. In the present report, we will summarize the rationale behind the use of ex vivo lung perfusion, the current different methodologies, and the published international experiences with its use.
\end{abstract}

Keywords Lung transplantation $\cdot$ Lung preservation $\cdot$ Ex vivo lung perfusion $\cdot$ Lung transplant outcomes $\cdot$ EVLP

\section{Introduction}

In the U.S., nearly 2,000 lung transplants are performed every year; however, many patients still die waiting for an organ [1]. More patients could be saved if more lungs met transplantation criteria.

Lung quality is the major limitation in the utilization of donated lungs [2]. The donor lung is subjected to significant physiological and biochemical stresses during brain death, often compounded by trauma, aspiration of gastric contents, and even embolization of trauma-fragmented brain tissue

This article is part of the Topical Collection on Artificial Organ CT Surgery.

P. G. Sanchez · B. P. Griffith $(\bowtie)$

Division of Cardiac Surgery, University of Maryland School of Medicine, 110 S PACA St. Heart Center 7th Floor, Baltimore, MD 21201, USA

e-mail: bgriffith@smail.umaryland.edu
[3]. Tissue injury during this process results in a systemic innate inflammatory response that compromises the homeostasis of the alveolo-capillary membrane leading to poor oxygenation [4]. Improving organ quality while suppressing this deregulated response before transplantation is highly desirable. Ex vivo lung perfusion (EVLP) provides us with the opportunity to re-evaluate and recondition lungs before transplantation [5].

The use of EVLP has generated great enthusiasm. Several centers around the world have presented encouraging results when using EVLP as a platform to screen organs from the substandard donor pool [6-9]. In addition, data from these centers have demonstrated equivalent outcomes when transplanting standard criteria lungs or lungs selected using EVLP.

The goal of this review is to summarize the rationale, background, and the current published clinical experiences with the use of ex vivo lung perfusion.

\section{Rationale for the Use of EVLP}

In the last decade, more aggressive pharmacological management has led to an increase in the number of organs placed per donor. But still only up to $20 \%$ of lungs offered are transplanted in most countries [10]. Cold ischemia, the current preferred method of lung preservation, reduces tissue metabolism limiting the opportunity for interventions after the lungs are explanted [11].

Ex vivo normothermic $\left(37^{\circ} \mathrm{C}\right)$ lung perfusion has been proven by our group and others as a reliable platform to screen lungs that had been previously rejected for transplant because of poor quality [12-15]. The ongoing NOVEL Trial has demonstrated that about $60 \%$ of the lungs evaluated improve their quality during EVLP [16••]. 
This quality improvement seems to be related to the low stress conditions of EVLP allowing the lung cells to regain a more physiological status before transplantation [17••]. Other favorable aspects of EVLP are the dehydration of the lung tissue by re-establishing Starling forces that may have been altered during brain death, and the re-expansion of atelectatic lung areas, which improve the ventilation/perfusion ratio leading to better gas exchange.

\section{Clinical EVLP Methodologies}

Contemporary clinical applications of EVLP could be summarized as: a method to increase the number of transplantable lungs by reconditioning unused/rejected lungs from the donor pool (Lund and Toronto's methods) $[6,9]$, and a method to replace cold preservation by using a transportable lung perfusion system (Organ Care System method) [18••]. Table 1 summarizes the differences and similarities between the steps followed by these methods during EVLP initiation and EVLP stable-reconditioning modes.

When following the Lund or Toronto method, lungs are procured in the standard fashion and transported cold to the recipient center where they are rewarmed for EVLP assessment. When following the OCS method, the lungs are procured in the standard fashion, cold flush, but immediately placed in the EVLP system for normothermic transport to the recipient center. Any of these methodologies requires a stepwise rewarming and an increase of flow in order to maintain pulmonary artery pressures under $15-20 \mathrm{mmHg}$. During the rewarming period, the vasculature is particularly fragile and elevated pressures can result in worsening edema by increased capillary filtration or by the irreversible loss of the alveolo-capillary barrier integrity [19]. Ventilation is started when the outflow reaches a temperature of $32{ }^{\circ} \mathrm{C}$. The ventilatory strategy is to maintain low airway pressures by using low tidal volumes, which, in combination
Table 1 Initiation and stablereconditioning modes in current EVLP methodologies

Hto hematocritum, $\mathrm{cmH} 2 \mathrm{O}$ centimeters of water, $\mathrm{P}^{\mathrm{O}_{2}}$ partial pressure of oxygen, bpm breath per minute, $b s a$ body surface area, $C O$ cardiac output, ${ }^{\circledR}$ trade mark, $P A$ pulmonary artery, $\mathrm{FiO}_{2}$ fraction of inspired oxygen, PEEP positive end expiratory pressure, $V T$ tidal volume

\begin{tabular}{|c|c|c|c|}
\hline & Lund's protocol [25] & Toronto's protocol [6] & $\begin{array}{l}\text { Organ Care } \\
\text { System }[18 \bullet \bullet]\end{array}$ \\
\hline Application & $\begin{array}{l}\text { Re-evaluation, } \\
\text { reconditioning after } \\
\text { procurement }\end{array}$ & $\begin{array}{l}\text { Re-evaluation, } \\
\text { reconditioning, } \\
\text { treatment after } \\
\text { procurement }\end{array}$ & $\begin{array}{l}\text { Replace cold } \\
\text { ischemia }\end{array}$ \\
\hline Transportable & No & No & Yes \\
\hline \multicolumn{4}{|l|}{ Flow } \\
\hline Pump type & Roller & Centrifugal & Pulsatile \\
\hline Start perfusion & $100 \mathrm{~mL} / \mathrm{min}$ & $150 \mathrm{~mL} / \mathrm{min}$ & $200 \mathrm{~mL} / \mathrm{min}$ \\
\hline Target total & $\begin{array}{l}100 \% \text { cardiac output } \\
(70 \mathrm{ml} / \mathrm{kg} \text { donor ideal } \\
\text { weight })\end{array}$ & $\begin{array}{c}40 \% \text { cardiac output } \\
\mathrm{CO}=3 \times \text { bsa }\end{array}$ & $2.5 \mathrm{~L} / \mathrm{min}$ \\
\hline \multicolumn{4}{|l|}{ Ventilation } \\
\hline Mode & Volume control & Volume control & Volume control \\
\hline VT & $\begin{array}{l}3-8 \mathrm{~mL} / \mathrm{kg}(1.5 \times \mathrm{PA} \\
\text { flow })\end{array}$ & $7 \mathrm{~mL} / \mathrm{kg}$ & $6 \mathrm{~mL} / \mathrm{kg}$ \\
\hline Frequency & $12 \mathrm{bpm}$ & $7 \mathrm{bpm}$ & $10 \mathrm{bpm}$ \\
\hline PEEP & $5 \mathrm{cmH} 2 \mathrm{O}$ & $5 \mathrm{cmH} 2 \mathrm{O}$ & $5 \mathrm{cmH} 2 \mathrm{O}$ \\
\hline $\mathrm{FiO}_{2}$ & $50 \%$ & $21 \%$ & $21 \%$ \\
\hline \multicolumn{4}{|l|}{ Pressure } \\
\hline Pulmonary artery & $<20 \mathrm{mmHg}$ & $<15 \mathrm{mmHg}$ & $<20 \mathrm{mmHg}$ \\
\hline Left atrium & $0 \mathrm{mmHg}$ & $3-5 \mathrm{mmHg}$ & $0 \mathrm{mmHg}$ \\
\hline \multicolumn{4}{|l|}{ Temperature } \\
\hline Start perfusion & $25^{\circ} \mathrm{C}$ & $25^{\circ} \mathrm{C}$ & $32{ }^{\circ} \mathrm{C}$ \\
\hline Start ventilation & $32{ }^{\circ} \mathrm{C}$ & $32{ }^{\circ} \mathrm{C}$ & $32{ }^{\circ} \mathrm{C}$ \\
\hline Start evaluation & $37^{\circ} \mathrm{C}$ & $37^{\circ} \mathrm{C}$ & $37^{\circ} \mathrm{C}$ \\
\hline Perfusate & $\begin{array}{l}\text { Steen solution }{ }^{\circledR}+\text { red } \\
\text { cells (Hto } 10-15 \%)\end{array}$ & Steen solution ${ }^{\circledR}$ & $\begin{array}{l}\text { Steen solution }{ }^{\circledR}+\text { red } \\
\text { cells (Hto } 15-25 \%)\end{array}$ \\
\hline Time to stability & $1 \mathrm{~h}$ & $1 \mathrm{~h}$ & $10-15 \mathrm{~min}$ \\
\hline Total time perfusion & $2-7$ h (92-393 min) & Up to $12 \mathrm{~h}$ & $\begin{array}{l}\text { Transport time } \\
\quad(188-622 \mathrm{~min})\end{array}$ \\
\hline
\end{tabular}


Table 2 Evaluation phase in current EVLP methodologies
Hto hematocritum, $\mathrm{cmH} 2 \mathrm{O}$ centimeters of water, $\mathrm{PO} 2$ partial pressure of oxygen, $\mathrm{bpm}$ breath per minute, $b s a$ body surface area, $C O$ cardiac output,

${ }^{\circledR}$ trade mark, $P A$ pulmonary artery, $\mathrm{FiO}_{2}$ fraction of inspired oxygen, $P E E P$ positive end expiratory pressure, $P V R$ pulmonary vascular resistance, $V T$ tidal volume, $N R$ not reported, $T x$ transplant

\begin{tabular}{|c|c|c|c|}
\hline & Lund's protocol [27] & Toronto's protocol [6] & $\begin{array}{l}\text { Organ Care } \\
\text { System }[18 \bullet \bullet]\end{array}$ \\
\hline Temperature & $37^{\circ} \mathrm{C}$ & $37^{\circ} \mathrm{C}$ & $37^{\circ} \mathrm{C}$ \\
\hline Flow & $\begin{array}{l}100 \% \text { cardiac output } \\
\text { (70 ml/kg donor ideal } \\
\text { weight) }\end{array}$ & $\begin{array}{c}40 \% \text { cardiac output } \\
\mathrm{CO}=3 \times \mathrm{bsa}\end{array}$ & $2.5 \mathrm{~L} / \mathrm{min}$ \\
\hline \multicolumn{4}{|l|}{ Ventilation } \\
\hline Mode & Volume control & Volume control & Volume control \\
\hline VT & $1.5 \times$ PA Flow & $10 \mathrm{ml} / \mathrm{kg}$ & $6 \mathrm{ml} / \mathrm{kg}$ \\
\hline Frequency & $12 \mathrm{bpm}$ & $10 \mathrm{bpm}$ & $10 \mathrm{bpm}$ \\
\hline PEEP & $5 \mathrm{cmH} 2 \mathrm{O}$ & $5 \mathrm{cmH} 2 \mathrm{O}$ & $5 \mathrm{cmH} 2 \mathrm{O}$ \\
\hline $\mathrm{FiO}_{2}$ & $50 \%-21 \%-100 \%$ & $100 \%$ & NR \\
\hline Recruitment maneuver & Incremental PEEP & $\begin{array}{l}\text { Inspiratory hold (max } \\
\text { peak pressure } \\
20 \mathrm{mmHg} \text { ) }\end{array}$ & NR \\
\hline \multicolumn{4}{|l|}{ Pressure } \\
\hline Pulmonary artery & $<20 \mathrm{mmHg}$ & $<15 \mathrm{mmHg}$ & $<20 \mathrm{mmHg}$ \\
\hline Left atrium & $0 \mathrm{mmHg}$ & $3-5 \mathrm{mmHg}$ & $0 \mathrm{mmHg}$ \\
\hline Deoxygenating gas & $7 \% \mathrm{CO}_{2}-93 \% \mathrm{~N}_{2}$ & $\begin{array}{l}8 \% \mathrm{CO}_{2}-6 \% \mathrm{O}_{2}-86 \% \\
\mathrm{~N}_{2}\end{array}$ & NR \\
\hline $\begin{array}{l}\text { Deoxygenating gas }(\mathrm{L} / \\
\text { min) titrated } \mathrm{PA} \mathrm{pCO}_{2}\end{array}$ & $34-38 \mathrm{mmHg}$ & $35-45 \mathrm{mmHg}$ & NR \\
\hline \multirow[t]{7}{*}{ Tx acceptance variables } & $\begin{array}{l}\mathrm{PO}_{2} / \mathrm{FiO}_{2}>300 \mathrm{mmHg} \\
\text { stable }\end{array}$ & $\begin{array}{l}\mathrm{PO}_{2} / \mathrm{FiO}_{2}>400 \mathrm{mmHg} \\
\text { stable: }\end{array}$ & $\mathrm{PO}_{2} / \mathrm{FiO}_{2}$ ratio \\
\hline & PVR & PA pressure & \multirow{4}{*}{$\begin{array}{l}\text { When system } \\
\text { stable at donor } \\
\text { site }\end{array}$} \\
\hline & Airway pressures & & \\
\hline & Lung compliance & PVR & \\
\hline & \multirow{3}{*}{$\begin{array}{l}\text { Absence of consolidation } \\
\text { lung collapse test }\end{array}$} & Airway pressures & \\
\hline & & Lung compliance & \multirow{2}{*}{$\begin{array}{l}\text { Before Tx at } \\
\text { recipient site }\end{array}$} \\
\hline & & $\begin{array}{l}\text { Clear chest X-ray } \\
\text { bronchoscopy }\end{array}$ & \\
\hline
\end{tabular}

with low vascular pressures, reduces the possibility of damaging the lungs by inducing stress failure [20-22].

A sweep gas flow is also initiated at $32{ }^{\circ} \mathrm{C}$. EVLP contains an oxygenator that works as a deoxygenator by using a sweep gas formulation of $7 \% \mathrm{CO}_{2}+93 \% \mathrm{~N}_{2}$ (Lund) or $8 \%$ $\mathrm{CO}_{2}+6 \% \mathrm{O}_{2}+86 \% \mathrm{~N}_{2}$ (Toronto). The flow rate is titrated to maintain a pulmonary arterial $\mathrm{PCO}_{2}$ of 34-38 (Lund) [9] or 35-45 mmHg (Toronto) [6]. Toronto recommends a 0.5-L/ min starting flow rate, and we have found that the final flow typically stabilizes at $2-4 \mathrm{~L} / \mathrm{min}$.

Once the outflow temperature reaches $37^{\circ} \mathrm{C}$, the system can be considered stable and the lungs can be evaluated. When following the Lund or Toronto methodology, lungs are re-evaluated every hour until they meet acceptability criteria for transplantation. If the lungs do not meet quality criteria, the system is placed back into a reconditioning mode and the lungs are re-evaluated an hour later. Given the low pressures and tidal volumes, alveolar recruitment maneuvers may be necessary through the perfusion time to ensure an adequate ventilation/perfusion ratio.
When using the Organ Care System for transport, a $\mathrm{PO}_{2} /$ $\mathrm{FiO}_{2}$ ratio is normally obtained at the donor site when the lungs are stable in the system and a second $\mathrm{PO}_{2} / \mathrm{FiO}_{2}$ ratio once in the recipient operating room before making the decision to transplant. Table 2 summarizes the evaluation mode and variables used to reassess lung quality during EVLP.

\section{Clinical Experiences with EVLP}

A review of www.clinicaltrials.gov revealed nine clinical trials studying the use of EVLP. Most of these trials are focused on the expansion of the usable lung donor pool, however one trial is looking at the effects of using a transportable EVLP system to replace cold ischemia as the standard of care. Table 3 shows the most relevant aspects of the clinical trials studying the use of EVLP.

Published literature, both in the form of abstracts and full reports, reveals that many centers are using different EVLP 
Table 3 Clinical trials registered at www.clinicaltrials.gov evaluating the use of EVLP

\begin{tabular}{|c|c|c|c|c|c|c|c|}
\hline Name & Code & Status & $\begin{array}{l}\text { Study } \\
\text { variable }\end{array}$ & $\begin{array}{l}\text { Inclusion } \\
\text { criteria }\end{array}$ & Primary endpoint & Center & Sponsor \\
\hline HELP & NCT01190059 & Completed & $\begin{array}{l}\text { Transplant } \\
\text { suitability }\end{array}$ & $\begin{array}{c}\text { High risk } \\
\text { donors }\end{array}$ & $\begin{array}{l}\text { PGD scores in the } \\
\text { first } 72 \mathrm{~h}, 30 \text {-day } \\
\text { mortality }\end{array}$ & Toronto & $\begin{array}{l}\text { XVIVO } \\
\text { Perfusion }\end{array}$ \\
\hline NOVEL & NCT01365429 & Recruiting & $\begin{array}{l}\text { Transplant } \\
\text { suitability }\end{array}$ & $\begin{array}{c}\text { High risk } \\
\text { donors }\end{array}$ & 30-day mortality & $\begin{array}{l}\text { Multicenter } \\
\text { (U.S centers) }\end{array}$ & $\begin{array}{l}\text { XVIVO } \\
\text { Perfusion }\end{array}$ \\
\hline EXPAND & NCT01963780 & $\begin{array}{c}\text { Not yet } \\
\text { open }\end{array}$ & $\begin{array}{l}\text { Transplant } \\
\text { suitability }\end{array}$ & $\begin{array}{c}\text { High risk } \\
\text { donors }\end{array}$ & $\begin{array}{l}\text { Composite: 30-day } \\
\text { mortality and } \\
\text { absence of PGD } 3 \\
\text { in the first } 72 \mathrm{~h}\end{array}$ & $\begin{array}{l}\text { Multicenter } \\
\text { (International) }\end{array}$ & TransMedics \\
\hline $\begin{array}{l}\text { Evaluation and } \\
\text { reconditioning of } \\
\text { marginal lung donors to } \\
\text { transplantation }\end{array}$ & NCT01353105 & $\begin{array}{c}\text { Not yet } \\
\text { open }\end{array}$ & $\begin{array}{l}\text { Transplant } \\
\text { suitability }\end{array}$ & $\begin{array}{c}\text { High risk } \\
\text { donors }\end{array}$ & $\begin{array}{l}\text { 30-day mortality } \\
\text { resp. complications } \\
\text { 12-month survival }\end{array}$ & $\begin{array}{l}\text { Sao Paulo, } \\
\text { Brazil }\end{array}$ & $\begin{array}{l}\text { InCor Heart } \\
\text { Institute }\end{array}$ \\
\hline $\begin{array}{l}\text { Ex vivo lung perfusion to } \\
\text { increase the number of } \\
\text { organs for } \\
\text { transplantation }\end{array}$ & NCT01967953 & Completed & $\begin{array}{l}\text { Transplant } \\
\text { suitability }\end{array}$ & $\begin{array}{c}\text { High risk } \\
\text { donors }\end{array}$ & $\begin{array}{l}\text { PGD scores in the } \\
\text { first } 72 \mathrm{~h}, 30 \text {-day } \\
\text { mortality }\end{array}$ & Milan, Italy & $\begin{array}{c}\text { Policlinico } \\
\text { Hospital }\end{array}$ \\
\hline $\begin{array}{l}\text { STRESS INDEX in lung } \\
\text { reconditioning }\end{array}$ & NCT01729637 & Completed & $\begin{array}{l}\text { Transplant } \\
\text { suitability }\end{array}$ & $\begin{array}{l}\text { High risk } \\
\text { donors }\end{array}$ & $\begin{array}{l}\text { Presence of } \\
\text { mechanical stress as } \\
\text { assessed by analysis } \\
\text { of the "Stress } \\
\text { Index" }\end{array}$ & Turin, Italy & $\begin{array}{l}\text { University } \\
\text { of Turin }\end{array}$ \\
\hline $\begin{array}{l}\text { Phase } 2 \text { study of ex vivo } \\
\text { perfusion and } \\
\text { ventilation of lungs to } \\
\text { assess transplant } \\
\text { suitability }\end{array}$ & NCT01241942 & Suspended & $\begin{array}{l}\text { Transplant } \\
\text { suitability }\end{array}$ & $\begin{array}{c}\text { High risk } \\
\text { donors }\end{array}$ & 30-day mortality & $\begin{array}{l}\text { University of } \\
\text { North } \\
\text { Carolina }\end{array}$ & $\begin{array}{l}\text { University } \\
\text { of North } \\
\text { Carolina, } \\
\text { Chapel } \\
\text { Hill }\end{array}$ \\
\hline $\begin{array}{l}\text { Ex vivo perfusion and } \\
\text { ventilation of lungs } \\
\text { recovered from non- } \\
\text { heart-beating donors }\end{array}$ & NCT01615484 & Recruiting & $\begin{array}{l}\text { Transplant } \\
\text { suitability }\end{array}$ & $\begin{array}{l}\text { Non- } \\
\text { heart- } \\
\text { beating } \\
\text { donors }\end{array}$ & 30-day mortality & $\begin{array}{l}\text { University of } \\
\text { North } \\
\text { Carolina, } \\
\text { Duke } \\
\text { University }\end{array}$ & $\begin{array}{l}\text { University } \\
\text { of North } \\
\text { Carolina, } \\
\text { Chapel } \\
\text { Hill }\end{array}$ \\
\hline INSPIRE & NCT01630434 & Recruiting & $\begin{array}{l}\text { Lung } \\
\text { preservation }\end{array}$ & $\begin{array}{l}\text { Lung } \\
\text { donor }\end{array}$ & $\begin{array}{l}\text { Composite: } 30 \text {-day } \\
\text { mortality and } \\
\text { absence of PGD } 3 \\
\text { in the first } 72 \mathrm{~h}\end{array}$ & $\begin{array}{l}\text { Multicenter } \\
\quad \text { (International) }\end{array}$ & TransMedics \\
\hline
\end{tabular}

$P G D$ primary graft dysfunction

methods to increase the number of usable lungs by screening the high risk donor pool. In addition, these reports demonstrate equivalent outcomes when using EVLP selected or standard criteria lungs, suggesting that EVLP is a safe method to increase the number of lung transplants.

\section{Transportable EVLP as a Method to Reduce Cold Ischemic Time}

In November 2012, the groups from Hannover and Madrid reported their initial experience using the Organ Care System as a method to reduce cold ischemia [18••]. Twelve patients received lungs from 12 donors whose lungs had been transported under normothermic ex vivo lung perfusion conditions. The mean running time of transportable EVLP was $303 \mathrm{~min}$, range 188-622 min. Lungs underwent a period of cold ischemia (i.e. time from harvest to start of EVLP and stop of EVLP to reperfusion after transplant), the mean cold ischemic time was $134 \mathrm{~min}$ for the first lung and $249 \mathrm{~min}$ for the second lung. The 30-day survival was $100 \%$, one patient died at day 140 after transplant from cardiomyopathy of unknown origin.

In 2013, the INSPIRE trial investigators (NCT01630434), presented their interim results after 60 lung transplants at the International Society of Heart and Lung Transplantation Society meeting in Montreal [23]; unfortunately, the published abstract does not provide information other than the number of lungs preserved using this methodology. 


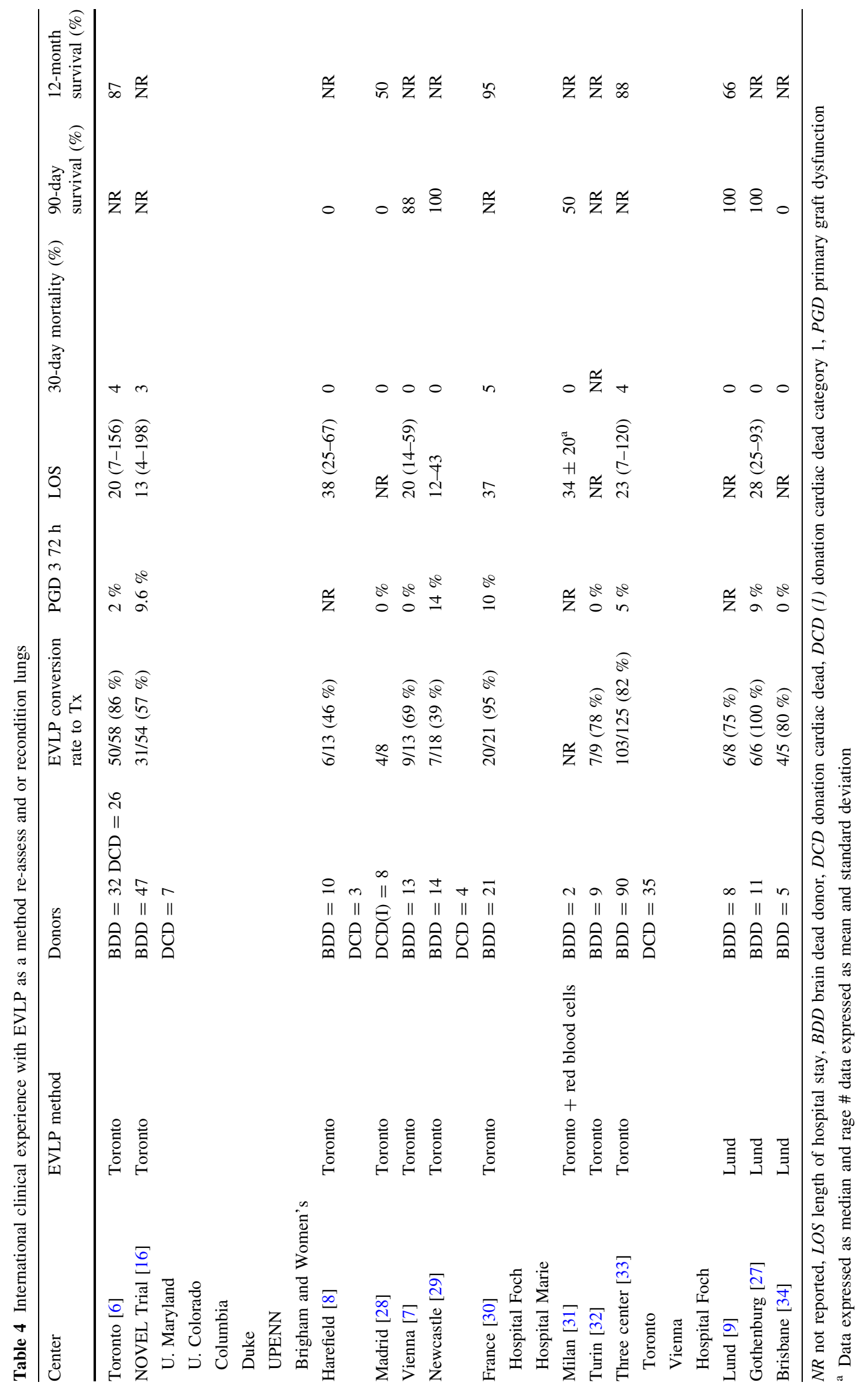




\section{EVLP as a Method to Re-assess and or Recondition} Organs from the Unused Lung Donor Pool

In 2001, Stig Steen [24] reported the first successful use of EVLP when a 54-year-old woman with COPD received a right lung from a 54-year-old donor who underwent cardiac arrest after myocardial infarction. Although initially the method was conceived to evaluate grafts from donors after cardiocirculatory arrest (DCD), Steen's group identified the potential of EVLP as a method to re-evaluate grafts originally rejected for transplantation based on their poor oxygenation. Subsequently in 2006, Wierup et al. [25] described their initial experience reconditioning six donors previously rejected by Scandiatransplant, Eurotransplant, and UK transplant organizations.

After his report, several centers recognized the value of EVLP in identifying good quality lungs within the donor pool that were not accepted for transplantation. One of these groups was the University of Toronto that not only identified the potential of EVLP for re-assessing and reconditioning lungs but also as a platform to deliver therapies looking to improve outcomes after transplantation. To achieve this, the Toronto group developed a low stress perfusion/ventilation strategy in order to maintain lungs ex vivo at a physiological body temperature for long periods of time, i.e. $12 \mathrm{~h}$. In 2011, the results from the first prospective clinical trial using EVLP, the HELP trial, conducted by the Toronto group were published [26••]. The results from this publication were expanded in 2012 when the group presented the outcomes after 50 transplants using lungs selected by EVLP [6]. Table 4 summarizes the most relevant outcome data for this experience.

Our group at the University of Maryland, in collaboration with five other lung transplant centers in the United States (Duke, Columbia, UPenn, University of Colorado, and Brigham's and Women), presented in 2013 the first multicenter and prospective clinical trial, the NOVEL Lung Trial, evaluating the safety of EVLP as a tool to screen the unused lung donor pool for good quality grafts [16••]. This report included 31 lung transplants using lungs selected from the marginal donor pool using EVLP and compared to 31 lung transplants using standard criteria donors. No significant differences in outcomes were observed between the groups as seen in Table 4 .

To date, several centers around the world have used this technique to re-evaluate organs from the substandard lung donor pool looking to increase the number of transplants. Table 4 summarizes the published data with the use of EVLP as a method to re-assess or recondition organs from the unused lung donor pool.

\section{Conclusions}

Published reports from different centers using EVLP, show a growing body of evidence that favor its use to screen the suboptimal donor pool. Safety concerns regarding its ability to recognize good quality grafts from the high-risk donor pool are diminishing as data from large multicenter and prospective trials are published. As for the effects of reducing cold ischemic time by using a transportable EVLP system, the ongoing INSPIRE trial may bring some clarity once the data is published.

EVLP promises a new era in lung transplantation, providing investigators with a reliable platform to translate new therapies to improve graft quality.

Compliance with Ethics Guidelines Disclosure The University of Maryland is one of eight centers conducting the NOVEL trial, an FDA trial sponsored by XVIVO Perfusion looking at the safety of EVLP to screen the donor pool. Pablo G. Sanchez and Bartley P. Griffith declare that they have no conflict of interest.

Human and Animal Rights and Informed Consent This article does not contain any studies with human or animal subjects performed by any of the authors.

\section{References}

References of interest which have been published recently are noted as:

- Of importance

- Of major importance

1. McCurry KR, Shearon TH, Edwards LB, et al. Lung transplantation in the United States, 1998-2007. Am J Transpl. 2009;9(4 Pt 2):942-58.

2. Van Raemdonck D, Neyrinck A, Verleden GM, et al. Lung donor selection and management. Proc Am Thorac Soc. 2009;6(1):28-38.

3. Rosendale BE, Keenan RJ, Duncan SR, et al. Donor cerebral emboli as a cause of acute graft dysfunction in lung transplantation. J Heart Lung Transpl. 1992;11(1 Pt 1):72-6.

4. Land WG. Emerging role of innate immunity in organ transplantation part III: the quest for transplant tolerance via prevention of oxidative allograft injury and its consequences. Transpl Rev (Orlando). 2012;26(2):88-102.

5. Sanchez PG, D’Ovidio F. Ex-vivo lung perfusion. Curr Opin Organ Transpl. 2012;17(5):490-5.

6. Cypel M, Yeung JC, Machuca T, et al. Experience with the first 50 ex vivo lung perfusions in clinical transplantation. $\mathrm{J}$ Thorac Cardiovasc Surg. 2012;144(5):1200-6.

7. Aigner C, Slama A, Hotzenecker K, et al. Clinical ex vivo lung perfusion-pushing the limits. Am J Transpl. 2012;12(7):1839-47.

8. Zych B, Popov AF, Stavri G, et al. Early outcomes of bilateral sequential single lung transplantation after ex vivo lung evaluation and reconditioning. J Heart Lung Transpl. 2012;31(3):274-81.

9. Ingemansson R, Eyjolfsson A, Mared L, et al. Clinical transplantation of initially rejected donor lungs after reconditioning ex vivo. Ann Thorac Surg. 2009;87(1):255-60.

10. Rosendale JD, Kauffman HM, McBride MA, et al. Aggressive pharmacologic donor management results in more transplanted organs. Transplantation. 2003;75(4):482-7.

11. Haniuda M, Dresler CM, Hasegawa $S$, et al. Changes in vascular permeability with ischemic time, temperature, and inspired oxygen 
fraction in isolated rabbit lungs. Ann Thorac Surg. 1994;57(3): 708-14.

12. Inci I, Hillinger $S$, Arni $S$, et al. Reconditioning of an injured lung graft with intrabronchial surfactant instillation in an ex vivo lung perfusion system followed by transplantation. J Surg Res. 2013;184(2):1143-9.

13. Sanchez PG, Bittle GJ, Williams K, et al. Ex vivo lung evaluation of prearrest heparinization in donation after cardiac death. Ann Surg. 2013;257(3):534-41.

14. Yeung JC, Wagnetz D, Cypel M, et al. Ex vivo adenoviral vector gene delivery results in decreased vector-associated inflammation pre- and post-lung transplantation in the pig. Mol Ther. 2012;20(6): 1204-11.

15. Dong B, Dong B, Stewart PW, Stewart PW, Egan TM. Postmortem and ex vivo carbon monoxide ventilation reduces injury in rat lungs transplanted from non-heart-beating donors. J Thorac Cardiovasc Surg. 2013;146(2):429e1-436e1.

16. • Sanchez PG, Davis RD, D'ovidio F, et al. Normothermic Ex vivo lung perfusion as an assessment of marginal donor lungsthe novel lung trial. J Heart Lung Transpl 2013; 32(4, Sup$\mathrm{pl})$ :S16-S17. First multicenter and propective clinical trial to study the safety of using EVLP to screen the suboptimal donor pool.

17. • Sanchez PG, Bittle GJ, Burdorf L, et al. State of art: clinical ex vivo lung perfusion: rationale, current status, and future directions. J Heart Lung Transplt 2012; 31(4):339-48. Comprehensive review of the phisiological and technical aspects regarding ex vivo lung perfusion.

18. •• Warnecke G, Moradiellos J, Tudorache I, et al. Normothermic perfusion of donor lungs for preservation and assessment with the Organ Care System Lung before bilateral transplantation: a pilot study of 12 patients. Lancet; 380(9856):1851-58. First report of transportable normothermic ex vivo lung perfusion.

19. Pierre AF, DeCampos KN, Liu M, et al. Rapid reperfusion causes stress failure in ischemic rat lungs. J Thorac Cardiovasc Surg. 1998;116(6):932-42.

20. Lunde PK, Waaler BA. Transvascular fluid balance in the lung. J Physiol. 1969;205(1):1-18.

21. West JB. Distribution of pulmonary blood flow and ventilation measured with radioactive gases. Scand J Respir Dis Suppl. 1966;62:9-13.

22. Hauge A, Nicolaysen G. Transvascular fluid balance and capillary permeability in the lung. Int Anesthesiol Clin. 1983; 21(2):1-26.
23. Warnecke G, Weigmann B, Van Raemdonck D, et al. The INSPIRE international lung trial with the Organ Care System technology $\left(\mathrm{OCS}^{\mathrm{TM}}\right)$. J Heart Lung Transpl. 2013;32(4, Suppl):S16.

24. Steen S, Sjoberg T, Pierre L, et al. Transplantation of lungs from a non-heart-beating donor. Lancet. 2001;357(9259):825-9.

25. Wierup P, Haraldsson A, Nilsson F, et al. Ex vivo evaluation of nonacceptable donor lungs. Ann Thorac Surg. 2006;81(2):460-6.

26. • Cypel M, Yeung JC, Liu M, et al. Normothermic ex vivo lung perfusion in clinical lung transplantation. $\mathrm{N}$ Engl $\mathrm{J}$ Med 2011;364(15):1431-40. First prospective clinical trial studying the use of ex vivo lung perfusion to screen the suboptimal donor pool.

27. Wallinder A, Ricksten SE, Silverborn M, et al. Early results in transplantation of initially rejected donor lungs after ex vivo lung perfusion: a case-control study. Eur J Cardiothorac Surg. 2014;45(1):40-5.

28. Moradiellos FJ, Naranjo JM, Córdoba M, et al. 90 Clinical lung transplantation after ex vivo evaluation of uncontrolled non heartbeating donors lungs: initial experience. J Heart Lung Transpl. 2011;30(4, Suppl):S38.

29. Dark JH, Karamanou D, Clark S, et al. 323 successful transplantation of unusable donor lungs using ex-vivo lung perfusion: the newcastle experience. J Heart Lung Transpl. 2012;31(4, Suppl):S115.

30. Sage E, Mussot S, Trebbia G, et al. O-097 lung transplantation of initially rejected donors after ex-vivo lung reconditioning: the French experience. Interact Cardiovas Thorac Surg. 2013;17 (suppl 1):S1-62.

31. Valenza F, Rosso L, Gatti S, et al. Extracorporeal lung perfusion and ventilation to improve donor lung function and increase the number of organs available for transplantation. Transpl Proc. 2012;44(7):1826-9.

32. Boffini M, Ricci D, Barbero C, et al. Ex vivo lung perfusion increases the pool of lung grafts: analysis of its potential and real impact on a lung transplant program. Transpl Proc. 2013;45(7): 2624-6.

33. Cypel M, Aigner C, Sage E, et al. Three center experience with clinical normothermic ex vivo lung perfusion. J Heart Lung Transpl. 2013;32(4, Suppl):S16.

34. Hopkins PM, Chambers DC, Naidoo R, et al. Australia's experience with ex-vivo lung perfusion of highly marginal donors. J Heart Lung Transpl. 2013;32(4, Suppl):S154. 